\title{
IDENTIFICATION OF COLLETOTRICHUM GLOEOSPORIOIDES, EXSEROHILUM ROSTRATUM AND GLIOCLADIUM VERMOESENI ASSOCIATED WITH LEAF ROT DISEASE OF COCONUT IN INDIA
}

By

\author{
N. Srinivasan* and M. Gunasakeran*
}

\section{SUMMARY}

Leaf rot is a common disease predominantly superimposed on root (wilt) affected coconut palms in India. Three fungi implicated in the disease have been found to be Colletotrichum gloeosporioides, Exserohilum Yostratum and Gliocladium vermoeseni. The cultural characters and morphological features of these fungi have been deBcribed. The pathogenic role of these fungi has been confirmed. The three fungi independently induced symptoms leading to leaf rot. E. rostratum developed the disease symptom relatively faster. Pin prick injury in leaf pieces generally favoured the fungi in infection and had pronounced effect for G. vermoeseni.

\section{INTRODUCTION}

Coconut leaf rol disease is rampant and generally superimposed on root (wilt) affected palms in southern districts of Kerala State, India. It appears on palms of all ages and intensity increase with age of the palms and advancement of root (wilt) disease (Radha and Lal, 1968; Srinivasan, 1991). The disease is important as it brings about rapid deterioration of affected palms. The annual yield loss due to leaf rot is estimated to be around 461 million nuts (Nair et al., 1991). The disease in the early phase appears in spindles as tiny, brown, necrotic, angular and sunken lesions which enlarge, coalesce and develop into severe rotting of tender tissues (Joseph and Rawther, 1991; Srinivasan and Gunasekaran, 1992).

Fungal etiological nature of the leaf rot has been attributed. McRae (1916) was the earliest to isolate a fungus from leaf rot diseased tissues. Menon and Nair (1951) isolated Helminthosporium halodes, Gloeosporium sp., Gliocladium roseum and Fusarium sp. from the diseased tissues and found that except Fusarium sp. others were pathogenic. H. halodes was found to be the most virulent fungus, others being secondary invaders. Subsequent reports centred especially on H. Hlodes (= Bipolaris halodes) in the causal relationship with leaf rot disease (Radha and Lal, 1968; Anonymous, 1979; Lily, 1981). Since the isolations were done only from a few palms, it was felt that isolations may be done from a large number of palms in different seasons (Srinivasan and Gunasekaran, 1993). Moreover, the need for studying the role of each fungus in the disease incidence, the taxonomical and cultural characters of the fungi involved was felt. The results emanated from such a study is presented in this paper.

*Central Plantation Crops Research Institute, Regional Station, Kayangulam, Krishnapuram - 690 533, Kerala, India. 


\section{MATERIALS AND METHODS}

\section{Isolation and identification}

Leaflets showing very early symptoms in affected spindles were cut into small bits $(0.5 \mathrm{~cm})$, surface sterilized with $0.1 \%$ mercuric chloride solution, rinsed in three sequential changes of sterile distilled water and plated onto Potato Dextrose Agar (PDA) in petriplates and incubated at $30+10 \mathrm{C}$ and observed for fungal growth. Leaf samples from different palms were used for isolation during different months. The fungi were subcultured, purified and grouped based on their apparent cultural characters. Representative cultures of these fungi were sent to CAB-International Mycological Institute, England for identification.

\section{Pathogenicity}

Pathogenicity was tested using pieces of detached leaflet or whole leaflet taken from healthy spindles. The leafletB were cleaned with sterile distilled water and used for inoculation as follows:

1. Leaflet pieces: leaflet pieces of approximately $70 \mathrm{~mm}$ length were cut and placed in sterile petriplateB (90 $\mathrm{mm}$ dia.) lined inside with moist filter paper. The leaflet pieces were inoculated by placing drops of inoculum containing spore suspension (approx. $4 \times 10^{5}$ spores $/ \mathrm{ml}$ ) either after pin prick injury or without injury separately at four locations on each leaflet piece. Ten succh leaflet pieces were used for inoculation by each fungUB. Controls were maintained by placing drops of sterile distilled water. The petriplates were incubated at room temperature (approx. $30^{\circ} \mathrm{C}$ ) and development of disease symptoms monitored at $24 \mathrm{hr}$. intervals.

2. Detached leaflets: Individual healthy leaflet detached from spindle was placed in test-tube $(150 \times 25 \mathrm{~mm})$ containing sterile distilled water with the upper portion of the leaflet projecting outside the test tube. The mouth of the tube was closed with sterile cotton wool to keep the leaflet in position. Thirty leaflets were spray inoculated per fungus. Mixed inoculum of all the three fungi was also used for spray-inoculation. Leaflets sprayed with sterile distilled water served as control. The tubes with leaflets were incubated inside bell jars at room temperature and symptom development monitored at 24 hr. intervals.

Reisolations of fungi involved were attempted when symptom development was noticed.

\section{RESULTS AND DISCUSSION}

Three fungi found predominant in the isolations were identified as Colletotrichum gloeosporioides (Penzig) Penzig \& Sacc., xserohilum rostratum (Drechsler) Leonard \& Suggs and liocladium vermoeseni (Biourge) Thom. by IMI (IMI 349539, IMI 349538 and IMI 349540).

\section{A. Cultural characters}

\section{Colletotrichum gloeosporioides (Penzig) \& Sacc.}

Colonies on PDA fast growing, greyish white with abundant aerial mycelium (Fig.1) and colony reverse bluish black. Growth was seen in concentric rings. The fungus consistently developed fructifications, acervuli in the medium with dark brown long setae. Conidia hyaline, aseptate, straight to slightly bent, slightly narrower in the middle and abtuse at the apices (Fig. 2). 


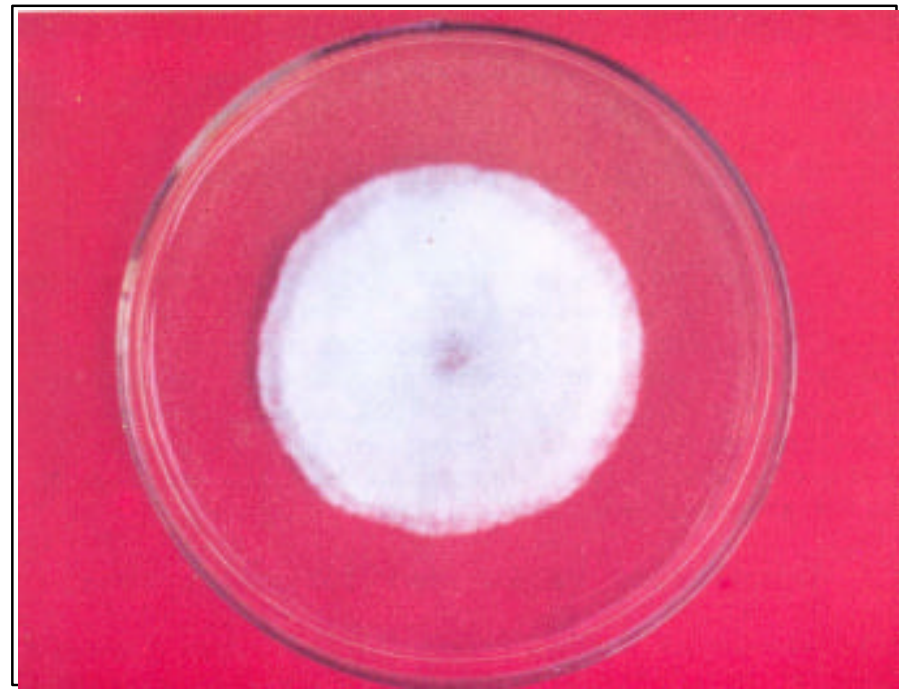

Fig. 1 - Collectotrichum gloeosporioides-culture

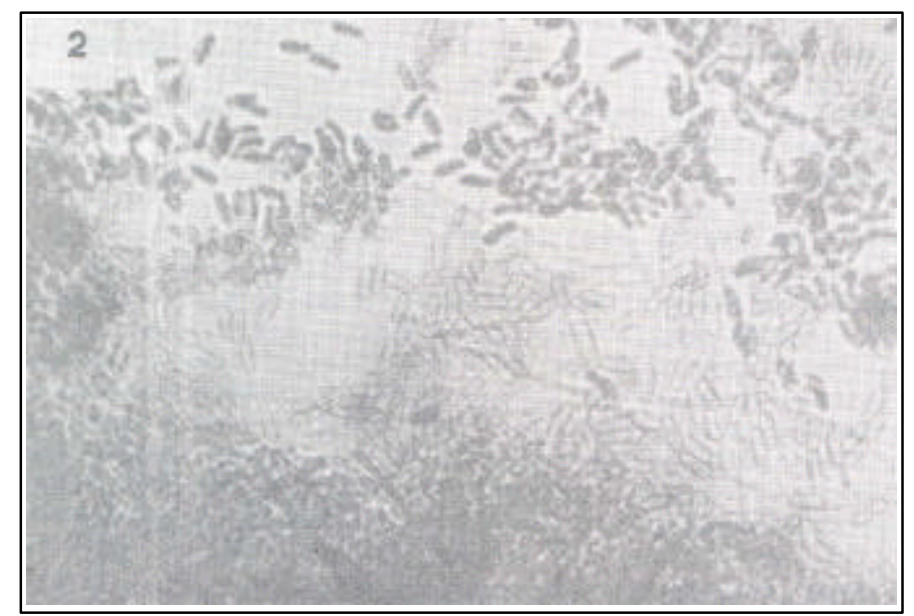

Fig. 2 Photomicrograph showing conidia

\section{Exserohilum rostratum (Drechsler) Leonard \& Suggs}

Colonies on PDA generally slow growing, effuse, dark greyish to olivaceous brown, velvetty (Fig.3) and colony reverse dark. Conidiophore simple, septate, olivaceous brown and geniculate conida straight or curved, brown to olivaceous, thick walled except in subhyaline region at the apex, hilum protruding from the basel cell, basal septum darker and thicker and upto 18 distoseptate (Fig.4).

\section{Gliocladium vermoeseni (Biourge) Thom}

Colonies on PDA whittish initially but turned to salmon or pink (Fig.5). The colony reverse olivaceous black on ageing. Conidiophore hyaline, septate, simple or penicillately branched terminating on phialids. Conidia hyaline, unicellular, oval to elliptical and pinkish or rose in masses (Fig.6). 


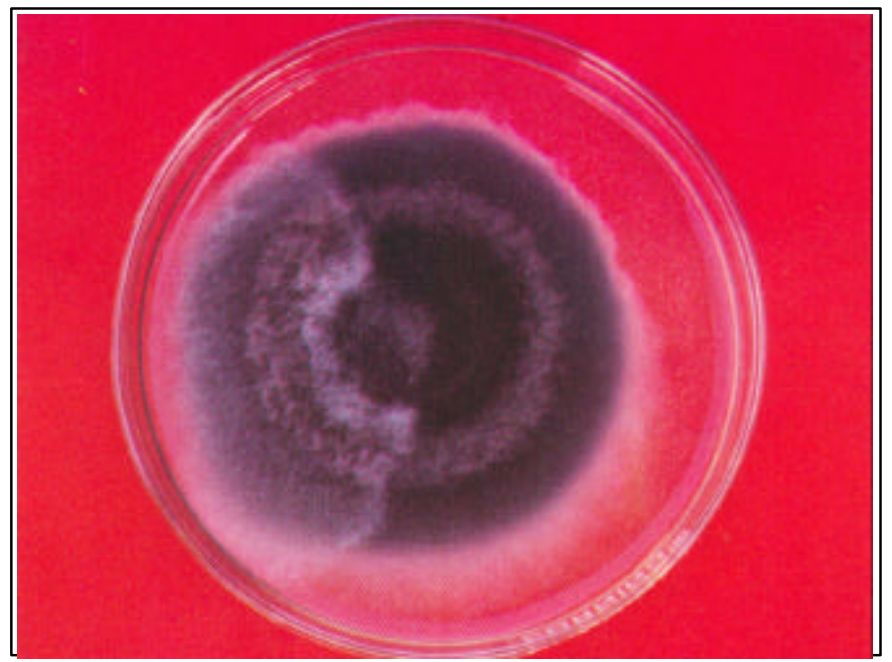

Fig. 3 Exserohilum rostratum culture

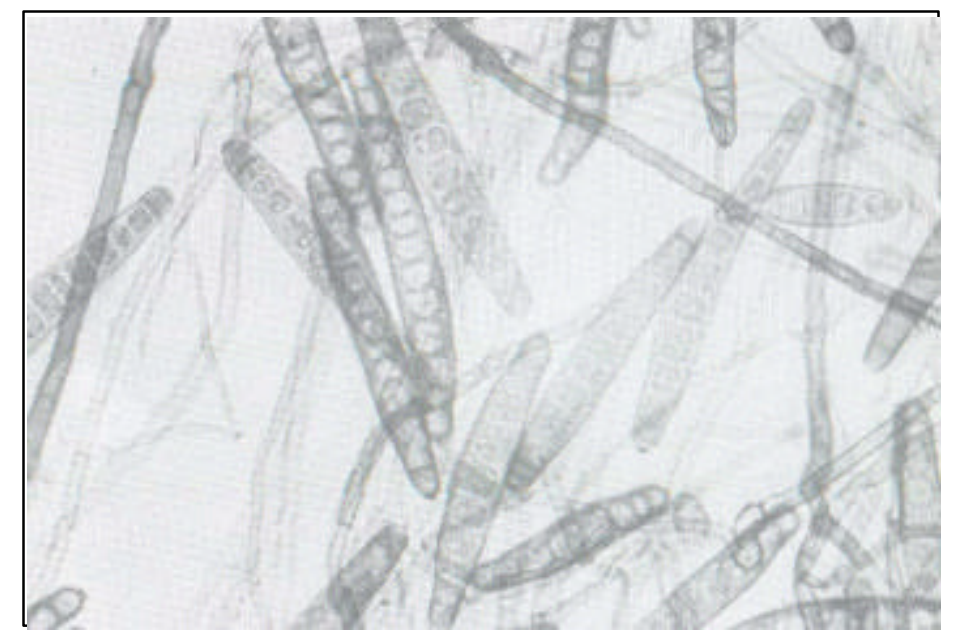

Fig. 4 Photomicrograph showing conidiophores and conidia

\section{B. Pathogenicity}

The results of pathogenicity tests are presented in Tables 1 and 2 .

All the three fungi viz., C. gloeosporioides, E.rostratum and G. vermoeseni induced $100 \%$ infection in leaflet pieces when inoculated with pin prick injury. The percentage recovery of the fungi from the lesions was 75,80 and 50 respectively (Table 1). When inoculation was done without pin prick the percentage infection was 40,60 and 30 only. In the case of detached whole leaflets, the respective percentage of infection was $86.7,96.7$ and 66.7 while it was $100 \%$ with mixed inoculum (Table 2).

In the leaflet pieces inoculated with C. gloeosporioides the symptom appeared as necrotic lesions which soon expanded and tissue rotten (Fig.7). In detached leaf lets the symptom appeared as minute, dark brown to greyish black, angular to irregular lesions. The early lesions appeared irrespective of margins, tips and intermittent areas of leaflets that coalesced to form large necrotic areas and leat tissue rotten within 5 days (Fig.8). 


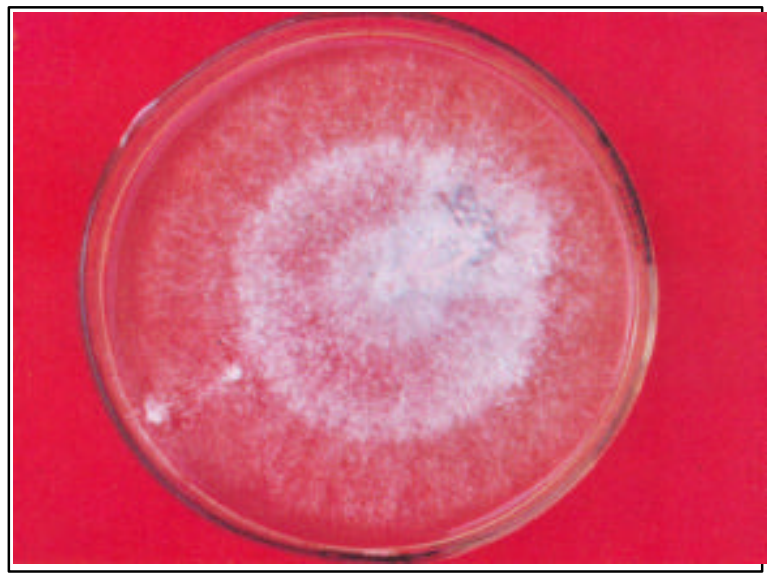

Fig. 5 Gliocladium vermoeseni - culture

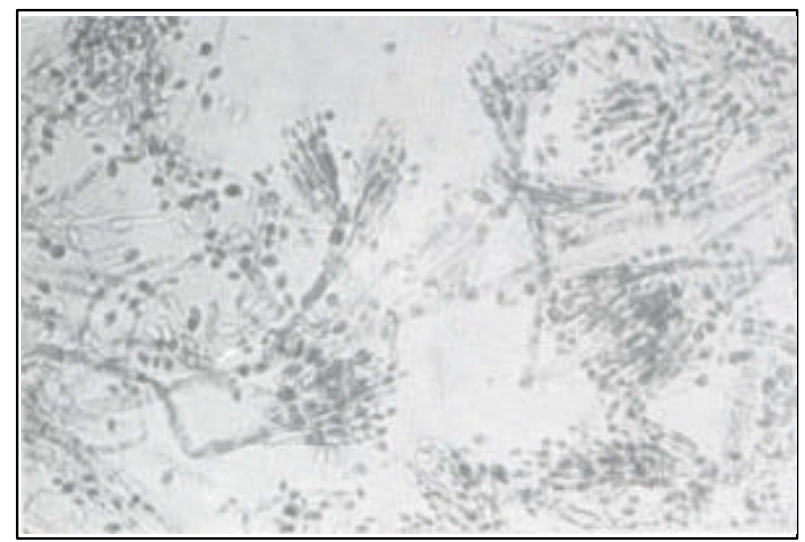

Fig. 6 Photomicrograph showing conidiophores

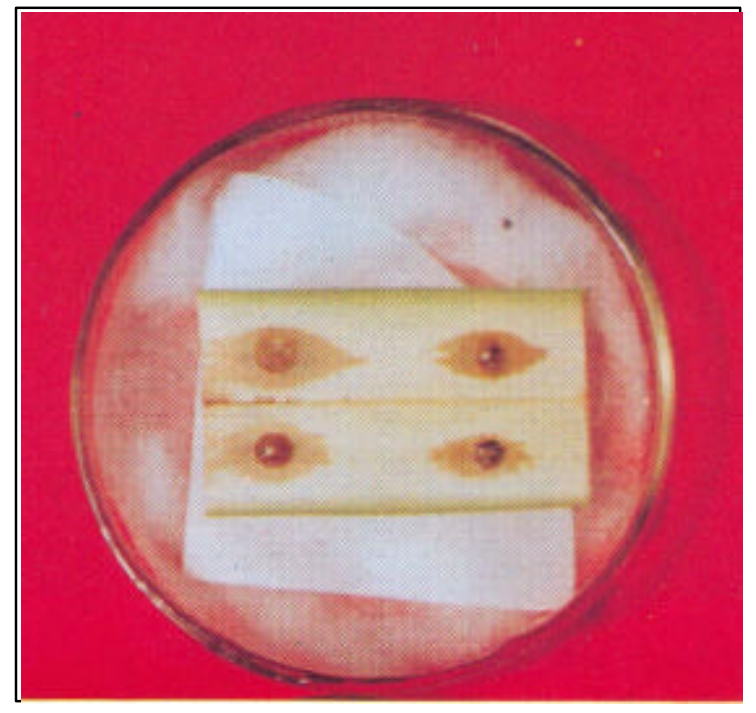

Fig. 7 Symptoms in leaflet pieces and detached leaflets (extreme leaf-healthy) 


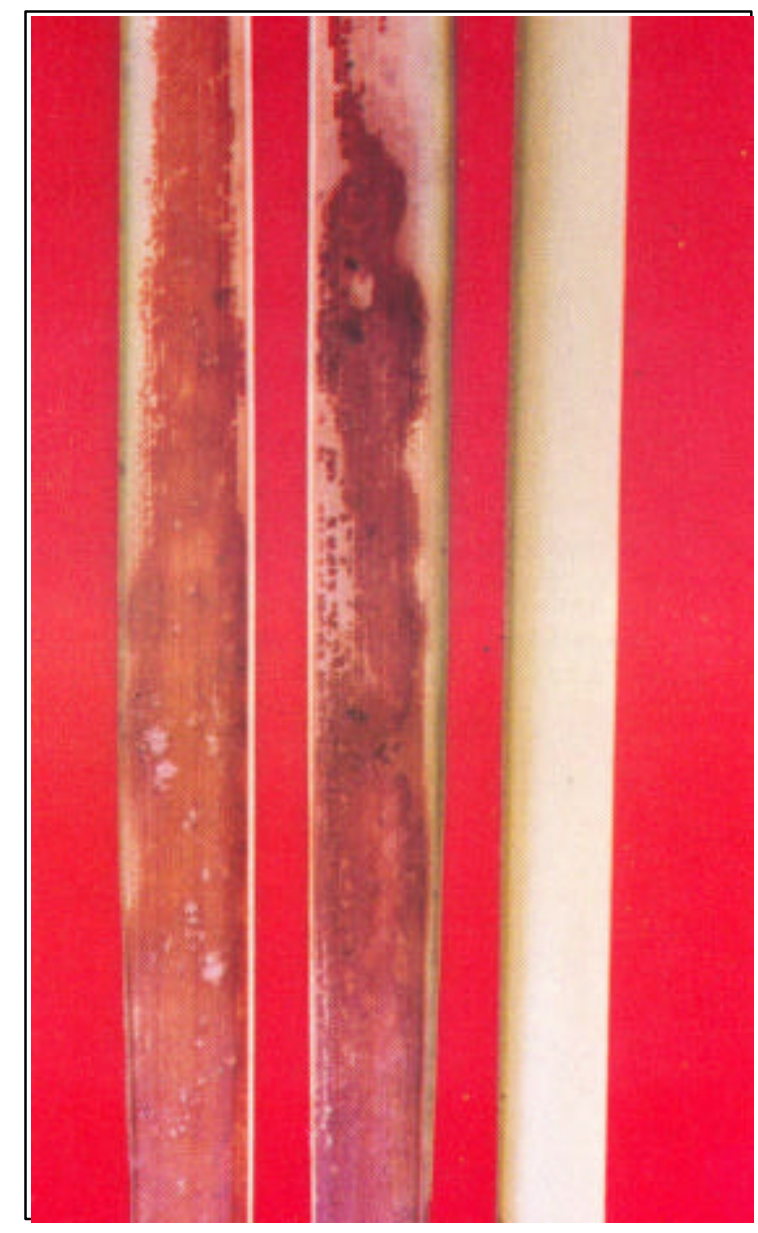

Fig. 8 Colletotrichum

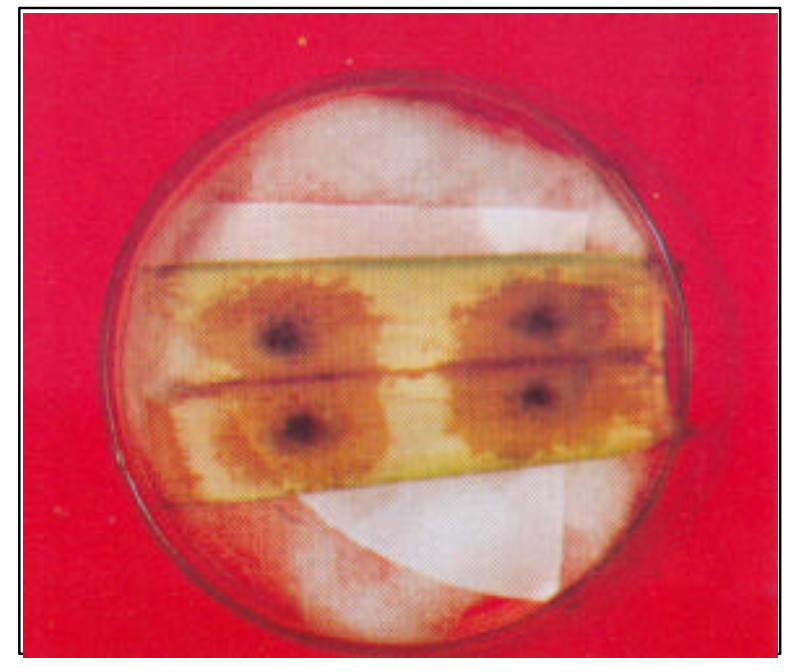

Fig. 9 Exserohilum 
In leaf pieces inoculated with E. rostratum, the fungus induced distinct necrotic lesions at points of inoculation. The lesions expanded faster resulting into extensive rotting of tissues (Fig.9), In detached leaflets, the early symptom appeared as tiny, water soaked lesions turning dark brown to black, elliptical to oval spots with a halo around and otr-white area at the centre. The lesions readily coalesced leading to extensive rotting of leaflets within 5 days after inoculation (Fig.10). E. rostratum is distributed in different countries and in India its association with graminicolous (Sivanesan, 1987) and other hosts (Mohanan and Sharma, 1986) has been reported.

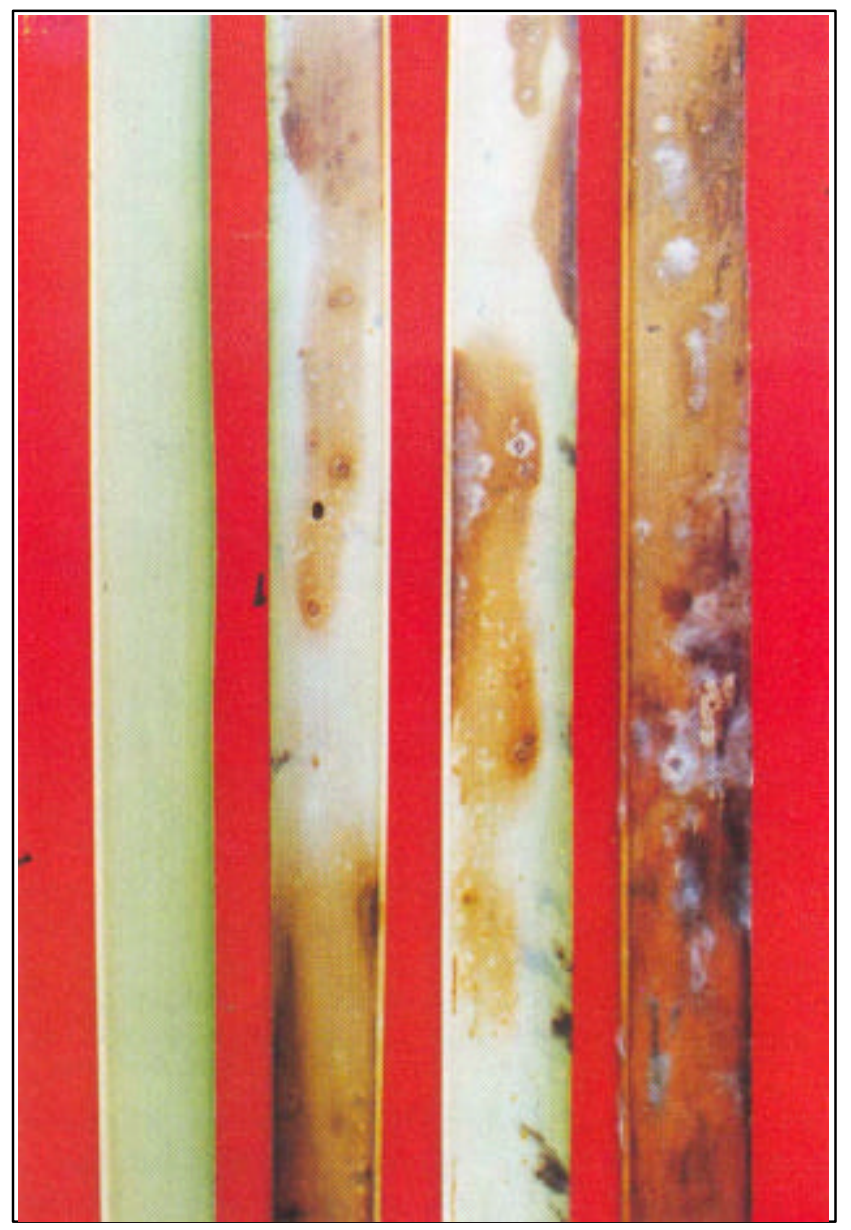

Fig. 10 Exserohilum rostratum

In leaf let pieces inoculated with G. vermoeseni the necrosis appeared at inoculated spots expanded to cause tissue rotting (Fig.11). In detached leaflets the fungus induced early symptoms as minute, necrotic specks, turned to circular to oval, brown spots with light brown margins. The lesions expanded and coalesced resulting in rotting of tissues (Fig.12). Reynolds (1964) reported Gliocladium disease of palm in Florida. Pathogenic association of G. vermoeseni with several palm species has also been reported by Atilango et al., (1980), Hodel (1985) and Hahn and Nussbaum (1986).

Among three species of fungi E. rostratum developed leaf rot symptoms relatively faster as compared to the others. Moreover, in detached whole leaflets inoculated with spray inoculation of spores, maximum infection $(96.7 \%)$ was obtained with E. rostratum. When the mixed inoculum of the three fungi was inoculated into leaflets, the infection was cent per cent. In reisolations from these infected leaflets, out of 60 leaf bits C. gloeosporioides was recovered from 40 bits (70\%) and $E$. 
rostratum from 36 bits (60\%), either singly or in combinations. G. Vermoeseni could not be reisolated (Table 2). The results pointed out predominance of E. rostratum and C. gloeosporioides over G. Vermoeseni. The frequency of symptom development by G. vermoeseni in leaflet pieces without pin pricks and in detached leaflets was comparatively lesser than that by other fungi. In general pin prick injury favoured all the three fungi to develop the disease in leaflet pieces. Atilango et al., (1980) reported that needle puncture favoured development of symptoms by G. vermoeseni in Chanaedorea palms since injury to leaflets was found to aid in the development of symptoms.

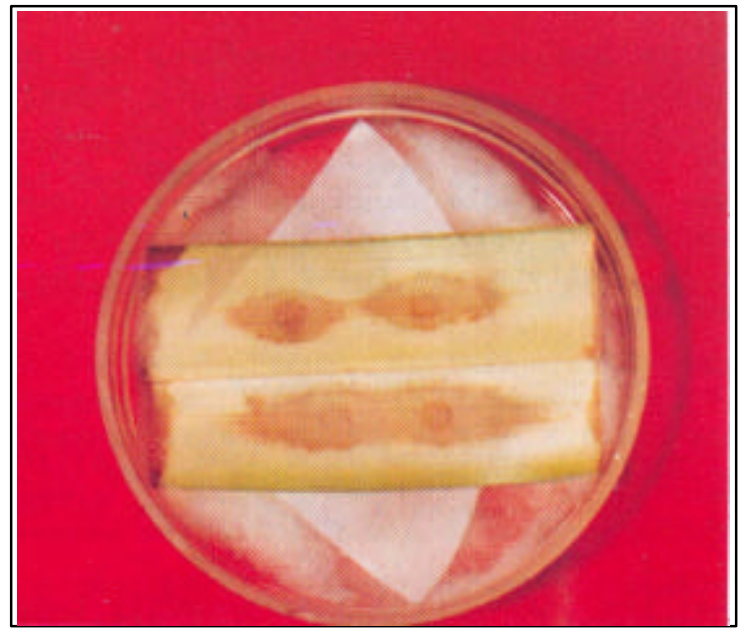

Fig. 11 Gliocladium

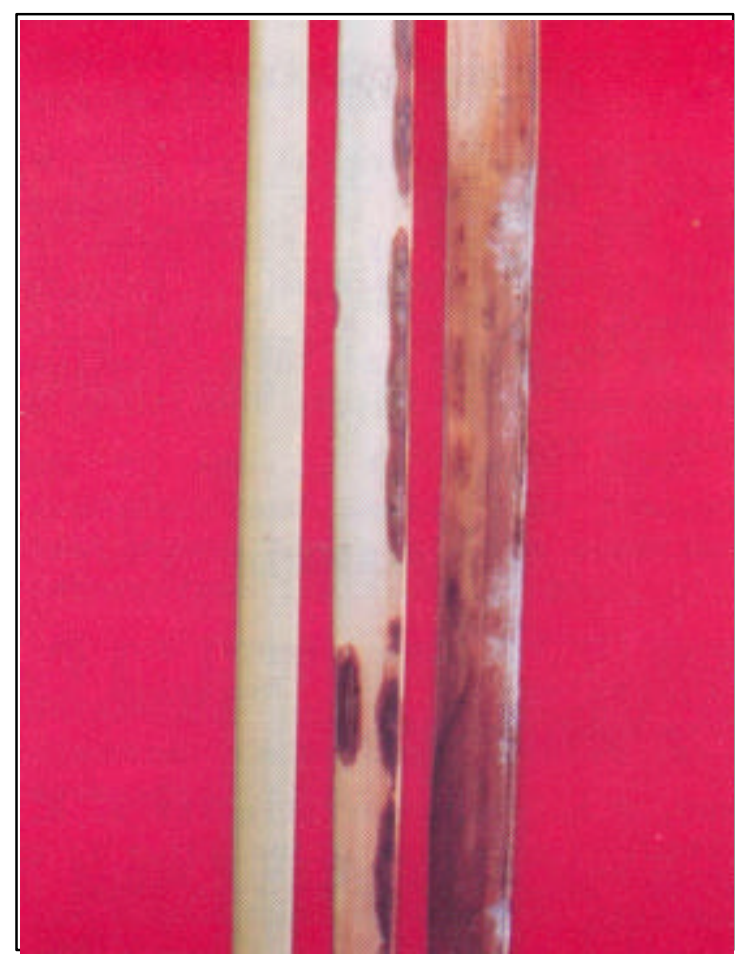

Fig. 12 Gliocladium vermiselemi 


\section{CONCLUSION}

1. The fungi isolated from leafrot affected spindle leaf lets are Colletotrichum gloeosporioides, Exserohilum rostratum and Gliocladium vermoeseni.

2. All the three fungi independently induced initial symptom leading to leaf rot. E. rostratum generally develop the disease vigorously and $\mathrm{G}$. vermoeseni comparatively slower.

\section{ACKNOWLEDGMENTS}

The authors are thankful to Dr. M.K. Nair, Director, CPCRI, Kasaragod for keen interest in the study and Dr. K.K.N. Nambiar, Acting Head, Division of Crop Protection, CPCRI, Kasaragod for encouragement and critical suggestions. They are grateful to Dr. B.C. Sutton, Head of Taxonomic and Identification Services, C.A.B. International Mycological Institute, England for identification of the fungi.

\section{REFERENCES}

1. Anonymous (1979): Annual Report for 1977. Central Plantation Crops Research Institute, Kasaragod, pp. 204.

2. ATILANGOf R.A., W.R. LDWELLYN AND Y. M. DONSELMAN (1980): Control of Gliocladium in Chanaedorea palms. Proc. of the Florida State Hort. Soc., 93 : 194 - 195.

3. HAHN, W. AND P. NUSSBAUM (1988): A new disease of palms in the GDR, caused by Gliocladium vermoeseni (Biourge) Thom. Nachrichtenblatt fur den Pflanzenschutz, 42:190-191.

4. HODEL, D. R. (1985): Gliocladium and Fusarium diseases of palms. Principes, 29: 85-88.

5. JOSEPH, T. AND T.S.S. RAWTHER (1991): Leafrot disease pp. 81-89. In coconut root (wilt) disease (Eds. Nair, M.K., K.K.N. Nambiar, P.K. Koshy and N.P. Jayasankar). Monograph series No.3, CPCRI, Kasaragod, 92 p.

6. LILY, V. G. (1981): Host parasite relation of Bipolaris halodes (Drechs). Shoemaker on the coconut palm. Indian Cocon. J., 11(11): 1-4.

7. MC RAE, W. (1916): Communication to the Dewan of Cochin. In Menon, K.P.V. and U.K. Nair 1948. The leafrot disease of coconuts in Travancore and Cochin. Indian Cocon. J.,1(2) : 33-39.

8. MENON, K.P.V. AND U.K. NAIR (1951): Scheme for the investigation of the root and leaf diseases of the coconut palm in South India. Consolidated final report of the work done from 8th March, 1937 to 31st March, 1948. Indian Cocon. J. 5(1):5-19.

9. MOHANAN, C. AND J. K. SHARMA (1986): Bipolaris specifera and Exserohilum rostratum causing leaf spots of Eucalyptus tereticornis - New record from India. Curr. Sci., 55: 990-992.

10. NAIR, M.K., K.K.N. NAMBIAR, P.K. KOSBY AND N.P. JAYASANKAR (1991): Coconut root (wilt) disease. Monograph series No.3, CPCRI, Kasaragod, 92 p. 
11. RADHA, K. AND S.B. LAL (1968) some observations on the occurrence of leaf rot disease of coconut and associated factors. 3rd Sessn. FAO Tech. Wkg. Pty. Cocon. Prod. Prot. and Proc. Jogjakarta, 1-5.

12. REYNOLDS, J.E. (1964): Gliocladium disease of palm in Dade County, Florida. Plant Dis.Rptr., 48: 718-720.

13. SIVANESAN, A. (1987). Setosphaeria generic description. In Graminicolous species of Bipolaris, Curvularia, Drechslera, Exserohilum and their Teleomorphs. Mytological Paper No. 158, CAB-IMI, England, 201-237.

14. SRINIVASAN, N. (1991) : Occurrence of Coconut leafrot in relation to root (wilt) disease. Indian Cocon. J., 21(10):14-18.

15. SRINIVASAN, N. AND M. GUNASEKARAN (1992): An appraisal of symptom expression in coconut due to leaf rot disease. Indian Cocon. J., 23(7):2-6.

16. SRINIVASAN, N. AND M. GUNASEKARAN (1993): Fungi associated with leaf rot disease of coconut. Indian Cocon. J. (Communicated). 
Table 1. Development of leaf rot in leaflet pieces of coconut Sprindle leaf by different fungi and resisolations

\begin{tabular}{|c|c|c|c|c|c|c|c|c|c|c|c|c|}
\hline \multicolumn{13}{|c|}{ Without pinprick inoculation } \\
\hline \multirow{2}{*}{$\begin{array}{l}\text { S. No. } \\
\text { Fungi }\end{array}$} & \multicolumn{4}{|c|}{ No. of leaflet pieces } & \multicolumn{5}{|c|}{$\begin{array}{l}\text { Reisolations No. of } \\
\text { Leaflets bits }\end{array}$} & \multicolumn{3}{|c|}{$\begin{array}{c}\text { No. of lead } \\
\text { pieces }\end{array}$} \\
\hline & $\begin{array}{l}\text { Ino- } \\
\text { Cula- } \\
\text { Ted }\end{array}$ & $\begin{array}{l}\text { Deve- } \\
\text { loped }\end{array}$ & $\%$ & $\begin{array}{l}\text { Inocu- } \\
\text { Lated } \\
\text { Into } \\
\text { Medium }\end{array}$ & $\begin{array}{c}\text { Esta- } \\
\text { Blished } \\
\text { Fungal } \\
\text { Growth }\end{array}$ & $\%$ & $\begin{array}{l}\text { Ino- } \\
\text { Cula } \\
\text { Ted }\end{array}$ & $\begin{array}{l}\text { Deve- } \\
\text { loped } \\
\text { Symp- } \\
\text { toms }\end{array}$ & $\%$ & $\begin{array}{l}\text { Inocu- } \\
\text { Lated } \\
\text { Into } \\
\text { Medium }\end{array}$ & $\begin{array}{c}\text { Esta- } \\
\text { Blished } \\
\text { Fungal } \\
\text { Growth }\end{array}$ & $\%$ \\
\hline $\begin{array}{l}\text { 1. Colleto- } \\
\text { trichum } \\
\text { gloeoso- } \\
\text { rioides }\end{array}$ & 10 & 4 & 40 & 20 & 15 & 75 & 10 & 10 & 100 & 20 & 15 & 75 \\
\hline $\begin{array}{l}\text { 2. Exserohilum } \\
\text { restratum }\end{array}$ & 10 & 6 & 60 & 20 & 14 & 70 & 10 & 10 & 100 & 20 & 16 & 80 \\
\hline $\begin{array}{l}\text { 3. Gliocladium } \\
\text { vermoeseni }\end{array}$ & 10 & 3 & 30 & 20 & 8 & 40 & 10 & 10 & 100 & 20 & 10 & 50 \\
\hline 4. Control & 10 & 0 & 0 & - & - & - & 10 & 10 & 0 & - & - & - \\
\hline
\end{tabular}

Table 2. Development of leaf rot in detached leaflets of coconut Spindle by different fungi and reisolations

\begin{tabular}{|c|c|c|c|c|c|c|}
\hline & \multicolumn{3}{|c|}{ No. of leaflets } & \multicolumn{3}{c|}{ Reisolation No. of leaflet bits } \\
\hline S. No. Fungi & $\begin{array}{c}\text { Inocu- } \\
\text { Late }\end{array}$ & $\begin{array}{c}\text { Deve- } \\
\text { loped } \\
\text { Symptom }\end{array}$ & $\%$ & $\begin{array}{c}\text { Inoculated } \\
\text { Into } \\
\text { medium }\end{array}$ & $\begin{array}{c}\text { Established } \\
\text { Fungal } \\
\text { Growth }\end{array}$ & $\%$ \\
\hline $\begin{array}{l}\text { 1. Colletotrichum } \\
\text { gloeosorioides (C) }\end{array}$ & 30 & 26 & 86.67 & 70 & 50 & 71.43 \\
$\begin{array}{l}\text { 2. Exserohilum } \\
\text { rostratum (E) }\end{array}$ & 30 & 29 & 96.67 & 85 & 69 & 81.18 \\
$\begin{array}{l}\text { 3. Gliocladium } \\
\text { vermoeseni (G) } \\
\begin{array}{l}\text { 4. Mixedinoculum } \\
\text { of all the above }\end{array}\end{array}$ & 30 & 20 & 66.67 & 40 & 25 & 62.50 \\
\begin{tabular}{l} 
5. Control \\
\hline
\end{tabular} & 30 & 0 & 100.00 & 60 & 60 & 100.00 \\
\hline
\end{tabular}

